\title{
The CIF Scene
}

\section{Annual meeting special guests}

Foresters were honored by the presence of two distinguished special guests at the Annual Meeting: Her Honour, Dr. Pauline M. McGibbon, Lieutenant-Governor of Ontario (left), and the Honourable Jeanne Sauvé, federal Minister for the Department of the Environment, are seen here with CIF President Dr. G. F. Weetman (left) and Mr. S. J. Simons, Vice-Pres.-Woodlands, The Ontario Paper Company Ltd.

Dr. McGibbon participated formally in the meeting, by speaking at the luncheon on the topic "The Arts as an Economic and Cultural Resource". Mme. Sauvé met with members of the CIF executive, displayed a most gratifying interest in the meeting activities, and agreed to meet and discuss forestry problems with CIF executive early in 1975 .

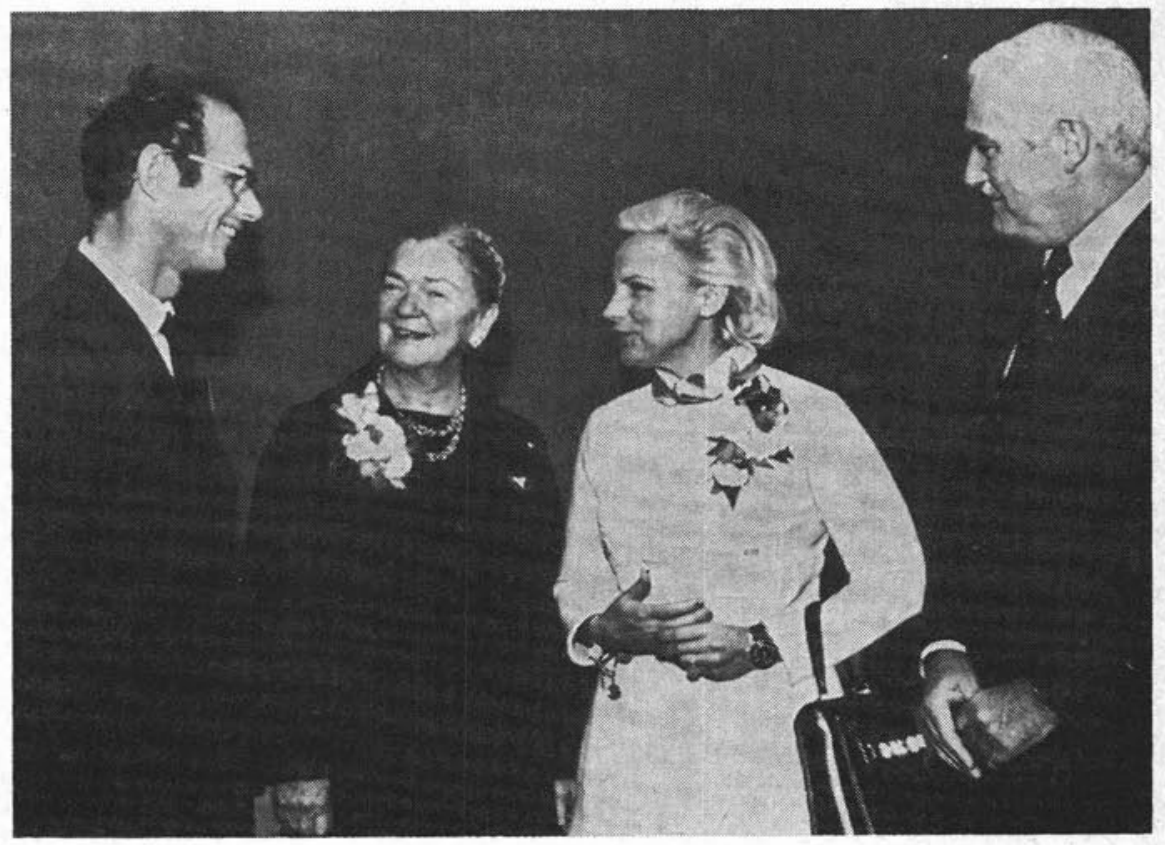

\section{CIF Gold Medal Winner}

At the annual fall social Mr. R. A. Baxter (right), Chairman of Northwestern Section of the CIF, presented Gary Russell Bloomfield with the Canadian Institute of Forestry Gold Medal of Merit. Mr. Bloomfield, a member of the second graduating class from Lakehead University has made a special request to share this honor with his wife Carolyn and daughters Shelly and Patricia for their special contributions towards this award during his period of university study.

Mr. Bloomfield received a Diploma in Forest Technology from Lakehead University in 1966 and worked with both private industry and government until returning to Lakehead in 1971 in the Bachelor of Science in Forestry Program. While completing his undergraduate studies, he received The Great Lakes Paper Co. Ltd. Scholarship, the I.B.M. Thomas J. Watson Memorial Bursary, and the Atkinson Charitable Foundation Bursary. He had the special honor of twice receiving Dr. Braun's Medal for highest standing in his graduating class, initially in 1966 and again along with his B.Sc.F. with First Class Honors in May, 1974.

Mr. Bloomfield is currently employed by The Great Lakes Paper Company, Limited, Thunder Bay, Ontario.

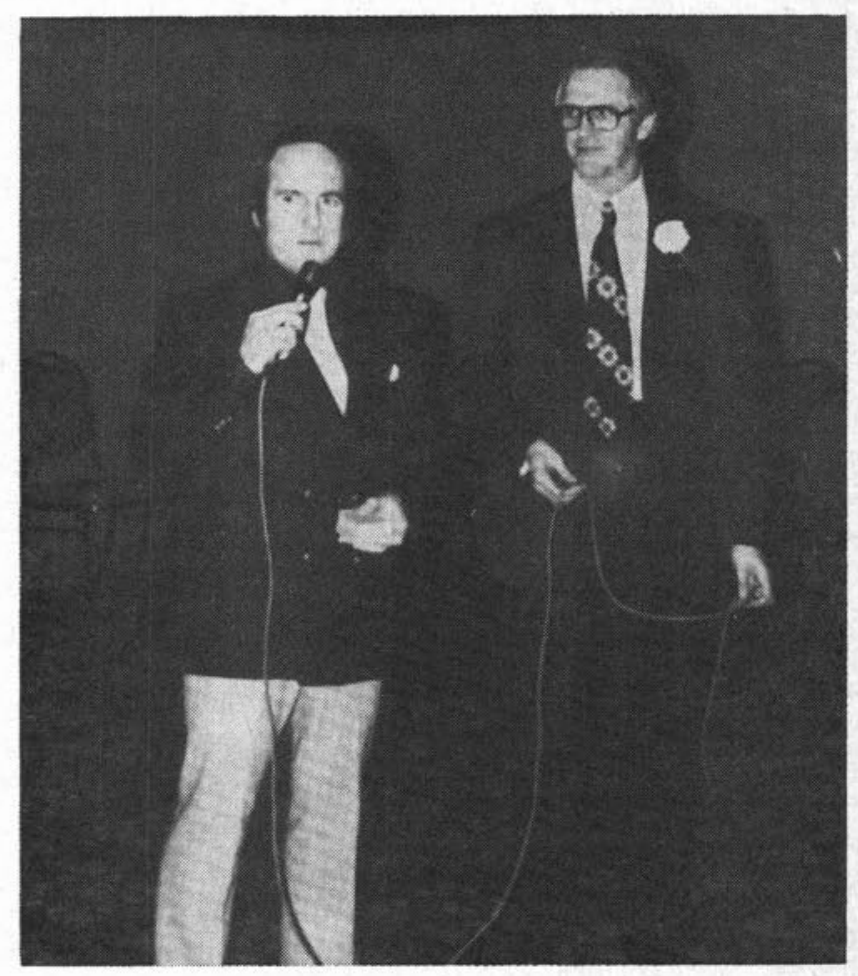


Nova Scotia Section

Bursary Awarded

Jim Stalker, a fourth year forestry student at the University of New Brunswick, and a native of Pictou County, Nova Scotia, received the Ninth Annual Bursary of $\$ 200$ awarded by the Nova Scotia Section CIF. F. G. Cuming, immediate past-chairman of the Nova Scotia Section, made the presentation to Mr. Stalker, shown at left, at a presentation attended by Dean of Forestry, J. W. Ker and other Faculty members.

\section{B.C.F.S. Old Timers Retire}

Two long-service members of the British Columbia Forest Service, Ted Whiting and Jack Long (left and right), completed their careers in 1974. They had a combined total of 85 years of duty during which they had many assignments. Particularly in recent years both men have been active in work with social as well as forestry implications.

Mr. Whiting played a leading role for the past 14 years in the B.C. forest camp program in which prison inmates work on a variety of forestry projects. $\mathrm{Mr}$. Long, since 1945, has worked on the development of many forest nursery programs as a reforestation specialist throughout the Province.

Prior to retirement both men were attached to the Reforestation Division, which may explain their plans to holiday with their wives in New Zealand where the man-made forest is said to justify a pilgrimage.

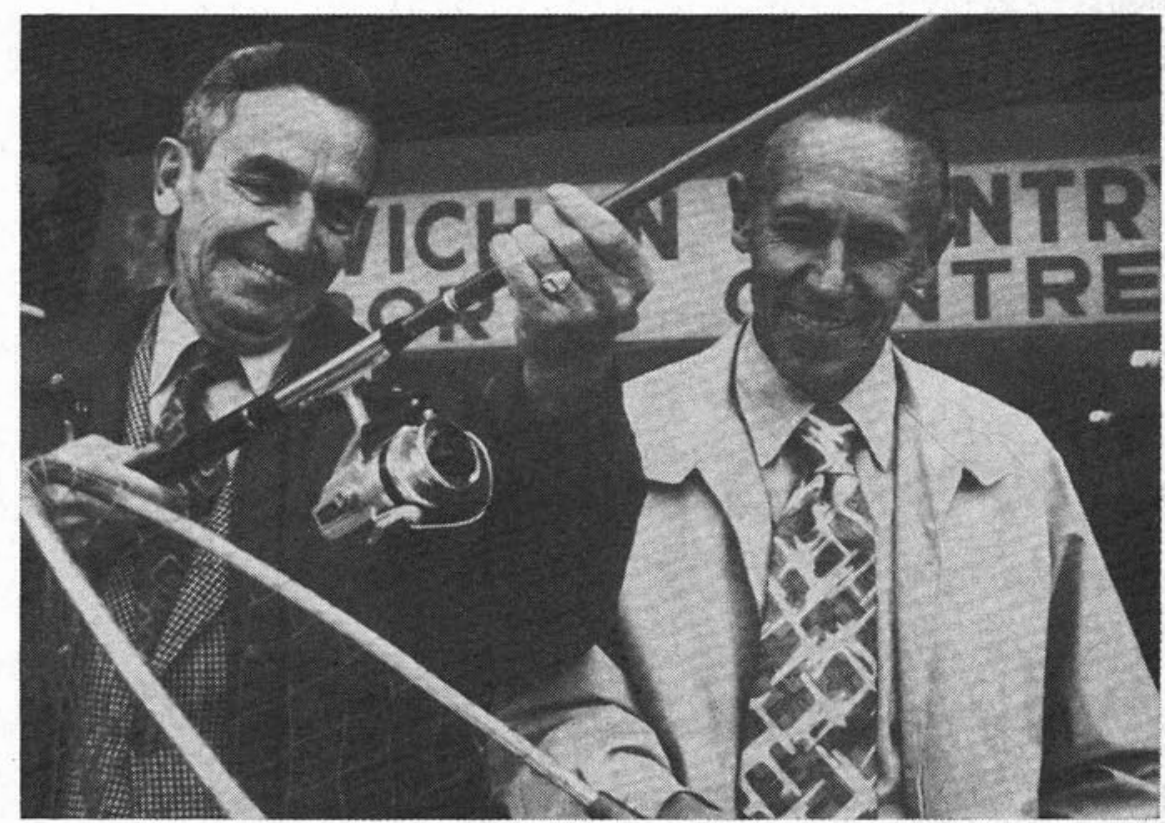

\section{A 50-year Chronicle}

At the $1974 \mathrm{CIF}$ annual meeting in Niagara Falls, editor Dave Fayle put together a 50th anniversary display featuring The Forestry Chronicle. Some of you saw it but all of you should, so those who were not at the meeting may check our picture. What you see represents 50 years of forestry in Canada.

The display was not large physically, but it was neat and complete. At a glance one could see the story of 50 years of evolution in size, format, decoration, and style. Another glance down a short list told of those who had edited The Chronicle throughout its life. Special events in that life; first cartoon, first use of color, first musical supplement; were documented. Paging through a few issues picked at random could hardly fail to produce the feeling that one was in the company of one's forestry ancestors.
In the presence of the 50 years of words - words which represented the thoughts of foresters through 50 years of Canadian forestry - one could not suppress a certain emotion. For an incoming editor it was both a sobering and inspiring experience - sobering because it invoked a realization of the responsibility being undertaken, inspiring because of the presence of evidence of the efforts of so many for so long.

Above all The Forestry Chronicle is our way of talking to each other from coast to coast. By its design it can serve to convey many kinds of information - from the highly technical to the expression of purely personal opinion. It can, as we have seen, inform, entertain, annoy, and even enrage. Having done this for half a century it has become a unique record of the profession.

\section{February 1975 The Forestry Chronicle}




\section{$\because 50 \& 25$ years $\because$}

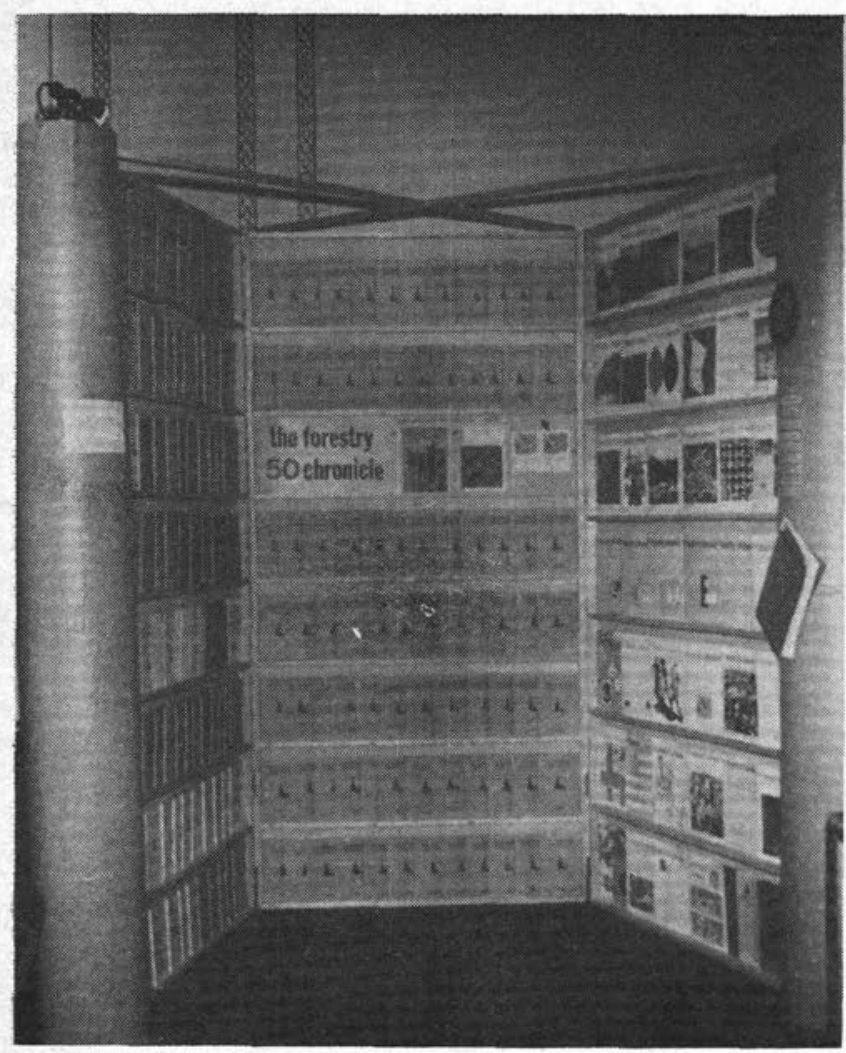

In the year 2024 some of today's younger CIF members will be present when some future editor will need more space than Dave Fayle used to show how things have gone with The Chronicle in its first 100 years. How the story turns out will be, above all, UP TO YOU.
1925. To the Members of the Society; I hope the News-letter presented to you in this form is only the precursor of a periodical journal for the discussion of matters of interest to the profession. Before we can have such a journal, however, we must demonstrate that we can support the News-letter more effectively than in the past. Don't leave all of the work to the Secretary. Send in your contributions of articles on subjects of interest. Only when successful in modest ventures can we pass on to greater.

sgd. C. D. Howe, President

Editor's note: And don't you forget it!

1950. It is said that there is nothing new under the sun, a statement the truth of which we scarcely can accept literally in these days of nuclear power, radar, and jet aircraft.

However that may be it is true that practice does, and must, lag behind research. In air survey this lag may be less than in other fields because the science, in its modern form, is so new. Even so the basic principles of photogrammetry were recognized and enunciated by Th. Scheimpflug before the close of the last century. He had by then constructed workable, though rudimentary, three dimensional photogrammetric apparatus.

The field of air survey is broad. In optics, there have been improvements in lens design, giving better resolution and less distortion. There have been improvements in photographic emulsions, in the film base, and in our knowledge of how to treat this base to avoid differential distortion. There is a better understanding of the effects, and proper uses, of various film-filter-emulsion combinations. There have been improvements in navigational aids to control lateral overlap, and in means to control fore and aft overlap. Again, a great improvement results from a growing knowledge of the economic consequences of using unsuitable photography

Perhaps there is nothing new under the sun. The formula we use is: sound techniques and exceptionally good men in the air and on the ground to apply them. There is nothing new in that.

Dr. Lyle G. Trorey

\section{Metric Conversion - Committee Report}

\section{METRIC CONVERSION IS COMING! and has been some} time - but who cares?

Well, I do for one. And so do your National Executive for several more. And so does.... but the list gets surprisingly long very quickly.

What is Metric Conversion? Simply stated, it is the planned co-ordinated change from present yard-pound units of measure to The International System (S.I.) of Units. For various good reasons Canada is making this change and we in Forestry must accommodate ourselves to the new measurement units.

At what stage is the Metric Conversion in Forestry? A brief history of the conversion process should help answer this question.

\section{January 1972}

The Metric Commission was established to promote an overall plan for the conversion.

Under the Metric Commission, eleven Steering Committees were formed to represent the various segments of the Canadian economy.

Finally, within each Steering Committee there are several Sector Committees, each charged with the details of conversion within their own field of endeavor.

Thus, Steering Committee No. 8 is responsible for the following:
8.1 - Forestry

8.2 - Wood Industries

8.3 - Furniture and Fixture Industries

8.4 - Paper and Allied Industries

8.5 - Printing, Publishing, and Allied Industries

July 1973

The organizational meeting of 8.1 - Forestry was held.

\section{December 1973}

Under 8.1 - Forestry the following sub-committees were formed:

8.1.1 - Research

8.1.2 - Inventory and Mapping

8.1.3 - Scaling

8.1.4 - Legislation and Regulations

8.1.5 - Planning and Implementation

\section{Highlights}

Sector 8.1 - Forestry unanimously passed the following resolution of 8.1.1 Research:

"No later than January 1975, all forest research publication will use the International System of Units (S.I.) as defined by Metric Practice Guide CSAZ 234.1 - latest revision, with English equivalents permitted. Assuming the peak of conversion implementation in 1977-78, by January 1978, such publications will omit the English equivalents." 
Based on recommendations from the various sub-committees, the Canadian Forestry Service published "Selected metric (S.I.) units and conversion factors for Canadian Forestry." (The first edition of 10,000 copies has been distributed and a second edition is contemplated.)

8.1.2 Inventory and Mapping have agreed that breast height is 1.3 meters above the ground, but cannot agree on ground level (i.e. uphill side, average of slope, etc.) Discussion continues on the selection of measurement class intervals and boundaries.

After 8 months of hard and good work, 8.1.3 - Scaling was disbanded in favour of a Canadian Standards Association Committee on Scaling in Metric (S.I.) Units of Primary Forest Products. This new Committee has held its organizational meeting and is starting work on the exacting task of producing Standard scaling procedures for all of Canada. The Committee is scheduled to have completed the necessary Standards by mid-1976 and to have produced a Scaling Manual by the end of that year. When should the forestry community be prepared to convert to S.I. Units? In general terms all new projects should be be initiated in S.I. Units. Existing projects should be converted to S.I. Units as the need arises, keeping in mind that the target-date for the completion of metric conversion in Canada is 1980 .

Suggestions? Opinions? Questions? - Please send them to: J. A. Benson, Chairman,

C.I.F./I.F.C. Committee For Metric

Conversion,

P.O. Box 1596,

Prince Albert, Sask.

S6V 5T2

\section{International Environmental Council}

At a recent meeting in Toronto representatives of Canadian and U.S. conservation organizations agreed to form a Canada-United States Environmental Council. Environmental questions of mutual interest and effective ways of dealing with them on a cooperative basis will be the principal concern of the Council. A steering committee composed of three representatives from each country will organize a second meeting of the Council in Washington, D.C. in March.

Nine Canadian organizations are participating at present and the Canadian contact is Theodore Mosquin of the Canadian Nature Federation. Conspicuous absentees from the list of founding organizations are the CIF and CFA in Canada and the SAF and AFA in the U.S.
Adoption of the working group concept by the CIF has aroused encouraging enthusiasm. They are seen as a means whereby a quantum leap may be made in the quality of communication within disciplines, within the CIF, between the $\mathrm{CIF}$ and governments, and with the public. The more optimistic believe that the working group effort will, in time, establish the CIF as a significant force in the understanding of, and management of, forest resources. Such a force has been too long absent and if it does develop can only come from the CIF.

Working groups must, therefore, be made to work and not only as ways for members to keep posted on what is happening in their particular field. Important as this is, it is only part of the battle and unless the effort goes beyond the personal the work will be essentially wasted.

The CIF has neither the money nor the votes to exert influences, good or bad, on forestry development. This is fortunate because it must then inevitably turn to the much more important resource that it does have - KNOWLEDGE.

Although the knowledge has always been there, the best intentions have usually been frustrated by the problem of mobilizing it. It has not often been possible to apply CIF expertise when and where it was needed. Working groups can provide a means of concentrating the right knowledge at the right place and time to make a proper contribution to the design and implementation of forest policies.

Working groups can probably do this but will they? Will early enthusiasm wane? Will the groups grow inward instead of outward? Will administrative lethargy set in? Only time will tell.

An optimistic attitude would be that working groups can, must, and will work because it can be clearly seen that the CIF must do whatever is necessary to put to use its collective knowledge and to fulfill its collective responsibility.

Working group chairmen will find a sympathetic ear at The Forestry Chronicle when they need assistance in advancing the efforts of their groups.

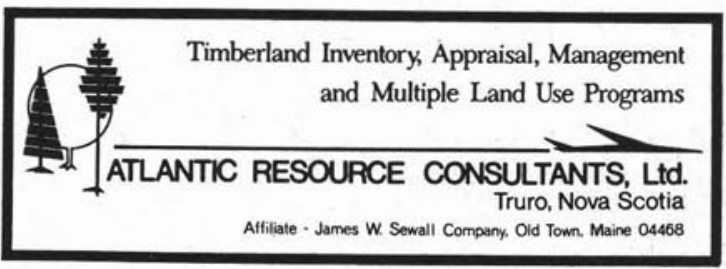




\section{Human Settlements}

It has long been my contention that any profession wishing to improve its image must go one step further than merely talking about its own problems. And I find that many foresters agree with me. Based on this premise, I accepted an invitation to the CIF to send a representative to the planning meeting for "Habitat '76".

It appears that Canada bid for and won the right to host the United Nations Conference on Human Settlements and it now will be held in Vancouver in 1976. The name for this Conference has been selected and authorized as "Habitat '76". When I first received the invitation I wasn't quite sure where forestry fitted into the picture of Human Settlements but it didn't take long after attending the meeting to realize that Human Settlements include everything from the barest of shelters to the greatest of megalopoli.

The meeting, which was held November 1 and 2, 1974, included delegates from a great many national non-government organizations, provincial non-government organizations, federal government observers, provincial government observers and others.

Habitat '76 itself will include delegates from 142 countries so naturally Canada, with its very high standard of living, feels that it has something to offer to this very important occasion. The comments of any member interested in input or information on Human Settlements in Canada or throughout the world would be greatly appreciated. I believe there is something that we can offer in this regard because of our expertise in the areas in which our work is done. Please do not hesitate to contact me if you are interested.

A. G. Racey

\section{Newfoundland Visit}

The Newfoundland Section is not only alive and well, it is enthusiastically and optimistically planning for a co-operative approach to healthy expansion in the forestry community of the Island. In a congenial atmosphere blending the humour, sincerity and integrity for which Newfoundlanders are well known, the delegates and guests at the 18th Annual Meeting of the Newfoundland Section, CIF, on December 2 and 3, 1974, laid down their duelling weapons of the past and embraced the challenge of concerted progress.

Over 60 members and guests attended the opening ceremonies and listened to the Honourable Harold Collins, Minister of Forestry and Agriculture, explain the new legislation and forest policy for Newfoundland. The legislation, which comes into effect shortly is the result of a task force which considered carefully the implications of the value of the forests to all and various users. Land tenure, land use, and sound forest management were carefully studied before the legislation was composed, and are emphasized in the final production. Full details on the legislation, its implications and the presentations and discussion during the meeting will be reported to The Forestry Chronicle by the News Representative so I will not elaborate further in this column.

However, there are one or two points I would like to make. Max Vardy, in particular, among other industry representatives speaking at the meeting, was quoted widely in the media that he felt the "Forestry policy can't be rushed" (The Evening Telegram). He said his company, Bowaters (Newfoundland) Ltd., welcomes any program that will ensure an adequate supply of timber in future years, but Max was quoted on the radio as saying it will take five or six years to gather the necessary information required by the government to be included in an "adequate" forest management plan. 
Being a mainlander, Max, I cannot say how close your inventoried information is to the required data. But I sincerely feel that with modern technology, modern aerial photography, the current use of computers to speed up collection and compilation of data surely five or six years is an inordinately long time. May I also respectfully submit that if the government insists on the necessity of such elaborate data as you imply - they should be willing to assist in the organization and implementation of the inventory method required.

Mac Squires pointed out that many forests on his company's limits (Price Newfoundland, now Abitibi) consist of "small sized trees" (even at maturity). It was suggested, and I agree, that there is a considerable potential in thinning and forest fertilization. Also possibly Marie Rauter with her Forest Tree Improvement Group (CIF Working Group \#7) might be of some assistance. You have not the only areas in Canada where are suppressed, unnaturally small trees.

To Minister Collins and Deputy Minister Norm Patrick, may I emphasize that although you now have the most modern and potentially valuable piece of forest legislation in Canada, the information demanded will in some cases be difficult to collect, compile and evaluate. As John Inder, Provincial Wildlife Service, said, "How do you place a dollar value on the therapeutic importance of a day in the woods?" I suggest, gentlemen, that close co-operation, and possibly even subsidy of the programs and plans desired, will be necessary.

Industry is established primarily to make a buck for its shareholders and only secondarily to improve and/or support the economic milieu of a given locale. It is government's mandate to ensure that industry, and therefore the economy, remains actively healthy.

Important items noted at the Newfoundland Section meeting included the obvious esprit de corps (objective " $d$ " of our constitution) and the co-operative and gentlemanly way constructive criticism was aired. The obvious understanding and support of the Minister and Deputy Minister for the profession in general and the CIF in particular was noted with considerable satisfaction on my part. And I can assure Mr. Collins that he has the full support of not only the Newfoundland Section of the CIF but of the National Body as well.

Incidentally, the attendance was swelled to over 100 when forestry students from Memorial University and the Technical College joined the group for the technical sessions.

Steve Holmes and his colleagues put a lot of work into the organization of the meeting and it was run smoothly and effectively by Chairman Ken Beanlands. May I congratulate the Newfoundland Section for their choice of Council. And may I assure the Newfoundland Section that the Forestry Community of Canada will hear of their expanding influence.

A. G. Racey
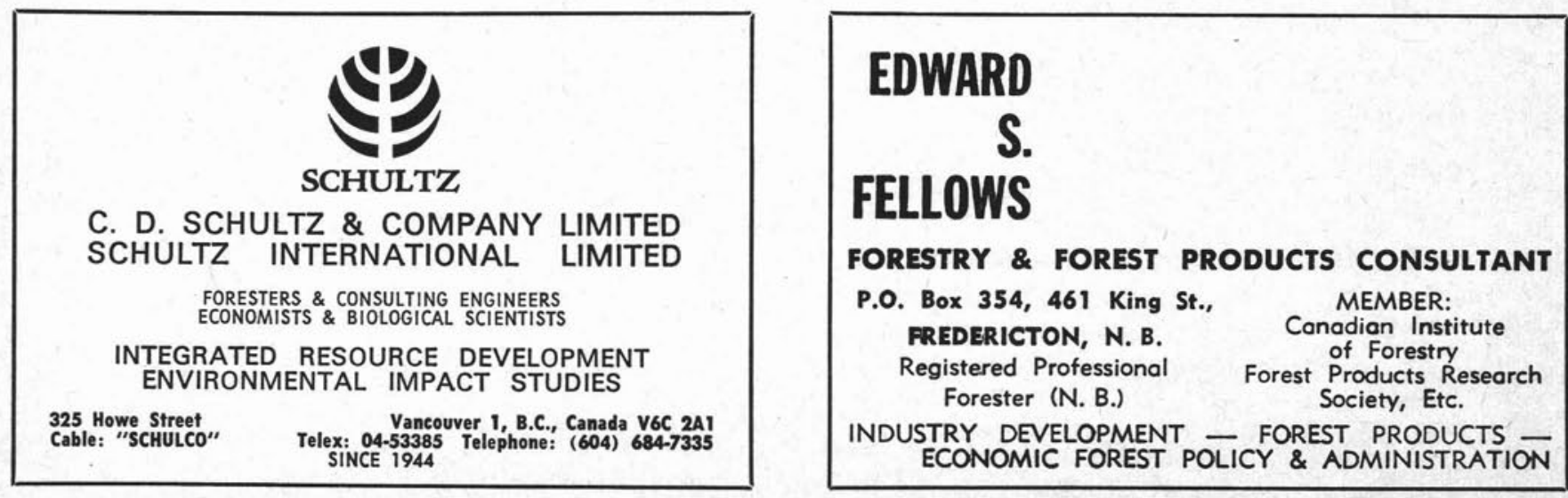